\title{
Dominant Rodent Species in Animal Production Farms at Sohag Governorate, Egypt
}

\author{
Abd El-Aleem Saad Soliman Desoky \\ Plant protection Department (Agriculture Zoology), Faculty of Agriculture, Sohag University, Egypt \\ *Corresponding Author: Abd El-Aleem Saad Soliman Desoky, Plant protection Department (Agriculture \\ Zoology), Faculty of Agriculture, Sohag University, Egypt
}

\begin{abstract}
The present work was aimed to identify of rodent species in animal production farms at the Experimental Stations of the Faculty of Agriculture, Sohag University, Sohag Governorate, Egypt, during 2015-2017 years. Four rodent species were found, one species belonged to family Cricetidae, named lesser garbia, Gerbillus gerbillus Olivier and three species of family muridae were recorded. Species of family muridae include field rat Arvicanthis niloticus Desmarest, grey bellied rat Rattus rattus alexandrinus Linnaeus, white bellied rat Rattus rattus frugivorus Linnaeus.
\end{abstract}

Keywords: Arvicanthis niloticus, Mus musculus, lesser garbia, Rattus rattus alexandrines, Rattus rattus frugivorus

\section{INTRODUCTION}

Rodents are known for their high reproductive potential, there are many interesting dynamics to various rodent populations that should be understood to better facilitate their management and to reduce damage. The population goes through an annual cycle that may include high and low densities, active and inactive periods, reproductive and non-reproductive periods, and dispersal periods. To avoid inclement periods, some species exhibit winter dormancy (hibernation), and some species have summer dormancy (estivation) during hot, dry periods. Some species exhibit multi-year cycles; for example, the rodents often reach population peaks (irruptions) every 3-5 years (Edge et al., 1995 and Wolff et al., 1997).

All rodents require food, shelter, and water. The shelter provides protection from predators, inclement weather, and a favorable place to bear and rear their young. Although rodents require water, those water requirements vary greatly by species. Because rodent food and cover (i.e., vegetation) can be influenced by human activities, there has been considerable development of strategies to reduce populations and damage by manipulating vegetation. We will discuss some of these habitat management approaches, but caution that many of them have not been thoroughly investigated or tested on a large scale (Barras and Seamans, 2002).

In Egypt, the changes of the environment by reclamation the desert and increase the cover plant in this area have been a great effect to the distribution of rodent species on abundance in the studied area (Desoky, 2007 and Abdel-Gawad, 2010). The present work was aimed to identify of rodent species at animal production farms to be used in the development of a future plan in effective strategy for implementation of rodent management programs in newly reclaimed land in Egypt.

\section{Materials ANd Methods}

The present work was carried out in animal production farms at the experimental stations of the Faculty of Agriculture, Sohag University in two area during March 2015 till February 2017 years.

Area (1) El-Kawther city It is located in newly reclaimed area at the Eastern desert area as arid region (15km. East of Sohag Governorate). This area has been planted from along period about (30 years) with isolated patches of vegetables, wheat, Egyptian clover, alfalfa, certain orchards and have a sheep farm, this farm about 10 Faddens, including the crops, buildings of animal sheds and animal food storages. 
Area (2) El-Kawamel city, it is located in newly reclaimed area at the Egypt western desert area (15 $\mathrm{km}$. west of Sohag Governorate). This area has been planted from along period about (15 years) with isolated patches of vegetables, wheat, Egyptian clover, alfalfa and certain orchards, and have a cattle and buffaloes farms, this farm about 10 Faddens, including the crops, buildings of animal sheds and animal food storages.

The present work was initiated to study the following main points:

- Identification of the different species of rodents

Rodent species were collected from the above mentioned sites by applying the common wire traps. Each trap was baited by bread and distributed twice every 15 days at $6 \mathrm{pm}$. Next morning at $7 \mathrm{am}$, traps were checked and rodents were identified and recorded for data processing. The captured rodents were classified and recorded.

\section{RESUltS AND DisCUSSION}

Data show the species composition of rodents trapped from study areas, El-Kawther city, El-Kawamel city. four rodent species were concerned as shown in table (1). One species belonged to family cricetidae, named lesser garbia G. gerbillus Olivier and three species of family muridae were recorded. Species of family muridae include field rat A. niloticus Desmarest, grey bellied rat Rattus $r$. alexandrinus Linnaeus, white bellied rat Rattus $r$. frugivorus Linnaeus, Norway rat $R$. norvegicus Berkenhout and house mouse Mus musculus Linnaeus.

Area (1) In El-Kawther city found that the presence of four species of rats included the white bellied rat, $R$. r. frugivorus, Rattus $r$. alexandrines, Nile grass rat, A. niloticus. and Lesser garbia, Gerbillus $\mathrm{sp}$ at the study area. Rattus $r$. frugivorus the dominant species, this may be due to the presence of attributed to the availability of food and shelter as well as prefers trees for nesting in houses. Also this may be due to the inter-specific competition between this species and other species. On the other hand $R$. norvegicus and Mus musculus were not captured by the traps

Area (2) In El-Kawamel city found that the presence of four species of rats included the white bellied rat, $R$. r r frugivorus, Rattus $r$. alexandrines, Nile grass rat, A. niloticus. and Lesser garbia, Gerbillus sp., at the study area. Rattus $r$. frugivorus the dominant species, this may be due to the presence of attributed to the availability of food and shelter as well as prefers trees for nesting in houses. Also this may be due to the inter-specific competition between this species and other species. On the other hand $R$. norvegicus and Mus musculus were not captured by the traps. These results to be used in the development of a future plan in effective strategy for implementation of rodent management programs in animal production farms.

Table (1). List of rodent species collected in animal production farms at the Experimental Stations of the Faculty of Agriculture, El-Kawther city and El-Kawamel city, Sohag University, during 2015-2017 years.

\begin{tabular}{|c|c|c|c|}
\hline \multicolumn{4}{|c|}{ Animal production farms } \\
\hline Rodent species & $\begin{array}{c}\text { El-Kawther city } \\
\text { (Eastern desert) } \\
\text { Cattle and buffaloes } \\
\text { farms } \\
\end{array}$ & $\begin{array}{l}\text { El-Kawamel city } \\
\text { (Western desert) } \\
\text { Sheep farm }\end{array}$ & Common name \\
\hline $\begin{array}{l}\text { Fam. Cricetidae: } \\
\text { Gerbillus gerbillus. } \\
\text { (Olivier) }\end{array}$ & $*$ & $* *$ & Lesser garbia \\
\hline $\begin{array}{l}\text { Fam. Muridae } \\
\text { Rattus rattus frugivorus } \\
\text { ( Linnaeus) }\end{array}$ & $* * *$ & $* * *$ & $\begin{array}{l}\text { white bellied rat, date palm } \\
\text { rat }\end{array}$ \\
\hline $\begin{array}{l}\text { Rattus rattus alexandrines } \\
\text { ( Linnaeus) }\end{array}$ & $*$ & $* *$ & grey bellied rat \\
\hline $\begin{array}{l}\text { Rattus norvegicus } \\
\text { Berkenhout }\end{array}$ & - & - & $\begin{array}{c}\text { Norway rat, Brown rat and } \\
\text { Sewer rat }\end{array}$ \\
\hline $\begin{array}{l}\text { Fam. Muridae } \\
\text { Arvicanthis niloticus }\end{array}$ & $*$ & $* *$ & $\begin{array}{c}\text { Field rat, grass rat, Nile rat, } \\
\text { Nile grass rat }\end{array}$ \\
\hline Mus musculus Linnaeus & - & - & House mouse \\
\hline
\end{tabular}




$$
\begin{aligned}
* * * & =\text { High population } \\
* * & =\text { Moderately population } \\
* & =\text { Slightly population } \\
- & =\text { Absent }
\end{aligned}
$$

The results similar with Ali (1985) recorded six species of rats and mice in Sohag Governorate. The species density percentages were arranged quantitatively in the following descending order $R$. norvegicus (35.17\%), A. niloticus (19.86\%), R. r. frugivorus (19.39\%), R. r. alexandrinus (13.88\%), M. musculus, (11.00\%), Acomys cahirinus (0.72\%).

Abdel-Gawad (1987) found those, three rodent species A. niloticus (Desm.), R. r. frugivorus and Gerbillus spp Desm., in Wady El-Assiuty area, Assiut Governorate. He noticed that, A. niloticus (Desm.) preferred areas planted with the field crops and some parts under cultivation beside old cultivated land while $R$. r. frugivorus was found in citrus orchards and around fanners buildings, whereas Gerbillus spp Desm., lived in desert and semi-desert parts where wild plants and weeds were grown.

Desoky et al., (2014) finding is in agreement with The results show in the experimental station of the Faculty of Agriculture, El-Kawther city, Sohag University, found that the presence of three species of rats included the Lesser garbia, Gerbillus sp. was recorded (1.08\%) from newly reclaimed area; the Nile grass rat, A. niloticus (4.44\%.) This may be attributed to the availability of food in neighbored field crops and vegetables plantations also, the white bellied rat, $R$. r. frugivorus the dominant specie $(94.27 \%$.) This may be due to several factors e.g., intra-specific competition, fecundity increasing and in habitat the ecosystems in which poultry buildings established in the faculty farm the presence of palm trees in the preparation of farm animal production, or poultry farm nearby, this provides shelter and increase in feed stores.

The differences in species composition of rodents depending on locality, neighboring, habitat type, inter specific compotation and preferred food (Desoky et al., 2014).Identification of rodent species in the study area can be used in the development of a future plan in effective strategy for implementation of rodent management programs in newly reclaimed land in Egypt. (El-Sherbiny, 1987 ; Desoky, 2007).

Desoky (2016) found that in the experimental station of the Faculty of Agriculture, El-Kawamel city, Sohag University in table (1) found that the presence of two species of rats included the Nile grass rat, A. niloticus $(27.52 \%$.) the white bellied rat, $R$. $r$. frugivorus the dominant specie $(72.48 \%$.) This may be due to the presence of attributed to the availability of food and shelter as well as prefers trees for nesting. On the other hand this may be due to the inter-specific competition between this species and other species.

\section{REFERENCES}

Abdel-Gawad KH (1987). Seasonal distribution of rodent species and their associated ectoparasites in new cultivated lands. Assiut J. Agric. Sc., 18 (3): 343-352.

Abdel-Gawad KH (2010). Rodent species composition in the present compared with past, the 5 Scientific Conferences for Agric. Assiut Univ. Oct. 16-17, 2010 (159-167).

Ali, MK (1985). Studies on rodents and their ectoparasites in Sohag Governorate. M.Sc. Thesis Fac. Agric., Assiut Univ.

Barras SC, Seamans TW (2002). Habitat management approaches for reducing wildlife use of airfields. Proceedings of the Vertebrate Pest Conference 20:309-315.

Desoky ASS (2007). Management strategies for rodents within different ecosystems. M. Sc. Thesis, Fac. Agric. Assiut Univ. 124.

Desoky ASS, Baghdadi SAS, Ahmed HSK (2014). Population density and seasonal distribution of rodent species at sheep farming in el-kawther city, Sohag region, Egypt. J. Plant Prot. and Path., Mansoura Univ., Vol. 5 (10): 903- 907.

Desoky ASS (2016). Fields Studies on Population Density and Seasonal Distribution of Rodent Species in Newly-Reclaimed Land, El-Kawamel city, Sohag Region, Egypt. Academic Web Journal of Agricultural Research Volume 1 issue 1 pp 001-003 July, 2016

Edge, WD, Wolff J, Carey RL (1995). Density-dependent responses of gray-tailed voles to mowing. Journal of Wildlife Management 59:245-251. 
El-sherbiny A H (1987). Cyclic fluctuation in rodent population: Review of current researches. Egypt wild and not resources Vo: 19 pp 17.

Wolff JO, Schauber EM, edge WD (1997). Effects of habitat loss and fragmentation on the behavior and demography of gray-tailed voles. Conservation Biology 11:945-956.

Citation: Abd El-Aleem S. S. Desoky, " Dominant Rodent Species in Animal Production Farms at Sohag Governorate, Egypt ", International Journal of Research Studies in Zoology, vol. 3, no. 4, p. 46-49, 2017. http://dx.doi.org/10.20431/2454-941X.0304006

Copyright: (C) 2017 Authors. This is an open-access article distributed under the terms of the Creative Commons Attribution License, which permits unrestricted use, distribution, and reproduction in any medium, provided the original author and source are credited. 